\title{
Comparative Study on Total Lipid Quantification and Oxidative Rancidity Determination in Freshwater Fish Species with Different Fat Levels
}

Ariane Vasconcellos de Alcântara, Pedro Lopes Azevedo, Eliane Teixeira Mársico, Maria Lúcia Guerra Monteiro (corresponding author), Bruna Leal Rodrigues, Carlos Adam Conte Júnior

Departamento de Tecnologia de Alimentos, Faculdade de Veterinaria, Universidade Federal Fluminense (UFF), Niteroi, 24230-340, Rio de Janeiro, Brazil, Telephone: 55-021-2629-9545 / Fax: 55-021-2629-9541

* Corresponding author: Telephone: 55-021-2629-9545 / Fax: 55-021-2629-9541

E-mail address: marialuciaguerra@yahoo.com.br (M. L. G. Monteiro)

Received: Sep 25, 2015 Accepted: Nov 5, 2015 Published: December 1, 2015

doi:10.5296/jfs.v4i1.8362 URL: http://dx.doi.org/10.5296/jfs.v4i1.8362

\begin{abstract}
The aim of this study was to investigate the efficiency of different extraction methods for total lipid determination and oxidative rancidity evaluation in freshwater fish with different fat levels. Total lipid content was determined by Bligh and Dyer with slight modifications and Soxhlet methods. Malondialdehyde (MDA) quantification was determined by analytical methods with and without heat application. In both freshwater fish species, Bligh and Dyer method extracted greater total lipid content $(P<0.05)$ than Soxhlet method. In addition, the heat method revealed higher MDA values $(P<0.05)$ compared to cold method in both lean fish (Cichla ocellaris) and high-fat fish species (Piaractus brachypomus). We concluded that, regardless of the fat content in the freshwater fish species, the Bligh and Dyer method and the cold method used for oxidative rancidity were more efficient than Soxhlet method and heat technique, respectively.
\end{abstract}

Keywords: Cichla ocellaris, Piaractus brachypomus, Malondialdehyde, Lipid stability, Oxidative rancidity, Total lipid content 


\section{Introduction}

Lipids are important components in foods which directly impact on sensory properties and diet consumer, mainly due to unsaturated fatty acids present on lipid fraction (Chowdhury et al., 2012; Collewet et al., 2013). Therefore, total lipid determination is essential for known food composition. Lipids are composed by nonpolar, neutral and polar components. Muscle foods contain mainly acylglycerides, cholesterol, free fatty acids (nonpolar compounds), and phospholipids or sphingolipids which are more polar lipids (Tocher \& Glencross, 2015; Wijaya et al., 2015). Nevertheless, lipid classes are highly variable depending of food matrices (Contarini \& Povolo, 2013; Dey et al., 2015). In freshwater fishes, neutral lipids (eg, triglycerides, and fatty acids) represent the lipid class more expressive followed by phospholipids (polar lipids) and glycolipids (Dey et al., 2015) which are amphipathic molecules containing hydrophilic and hydrophobic portions (Ikami et al., 2000).

Several methodologies are used for total lipids determination, however, there is a lack of study comparing lipid extraction methods more often used taking into consideration food matrix evaluated, required analysis time, and factors regarding solvents applied in the analysis such as type and volume, which directly affect the amount of extracted fat (Brum et al., 2009; Kus et al., 2009; Tonial et al., 2009). Soxhlet (1879) and Bligh and Dyer (1959) methods are more commonly used for total lipids determination in fish meat (Palmeira et al., 2014a; Canto et al., 2015; Monteiro et al., 2015). Soxhlet and Bligh and Dyer methodologies are based on fat extraction utilizing organic solvents such as ether and chloroform, respectively, due to great solubility of the fat molecules on these chemical solvents (Brum et al., 2009).

Moreover, studies about lipid deterioration in fish are very important due to high susceptibility of the unsaturated fatty acids to lipid oxidation resulting on formation of intermediate (peroxides and hydroperoxides) and secondary (aldehydes, ketones, carbonyls, alcohols, and acids) compounds which negatively impact flavor and human health (Chaijan, 2008; Bertolin et al., 2011; Duthie et al., 2013; Zaki et al., 2014). Malondialdehyde (MDA) is considered the main secondary compound from lipid decomposition and their quantification is commonly used as indicator of oxidative rancidity in fishes (Monteiro et al., 2012; Palmeira et al., 2014b). There are several methods for MDA determination which basically differ in terms of the extraction method (distillation or acid addition and hot or cold extraction) (Tarladgis et al., 1960; Yin et al., 1993; Monteiro et al., 2012; Karlsdottir et al., 2014). However, the main methods used in fish are those proposed by Tarladgis et al. (1960) and Yin et al. (1993). These methodologies are based on the reaction of one molecule of MDA with two molecules of 2-thiobarbituric acid (TBA) resulting in a stable pink chromophore. These methods are called thiobarbituric acid reactive substance (TBARS) tests and the results are expressed as mg of MDA per $1 \mathrm{~kg}$ of sample or TBA-number (Tarladgis et al., 1960; Yin et al., 1993; Monteiro et al., 2012; Karsldottir et al., 2014).

Despite Soxhlet method (Soxhlet, 1879) is widely used and represents the official methodology for total lipids determination (AOAC, 2012), this methodology presents some disadvantages such as long time required and reflux distillation apparatus leading to 
excessive use of water and solvent. Furthermore, petroleum ether is unique solvent used in this method resulting only in apolar lipids extraction. Nonetheless, in Bligh and Dyer method (Bligh \& Dyer, 1979) a solvent mixture of methanol-chloroform $(2: 1, \mathrm{v} / \mathrm{v})$ is used which leads to great efficiency on total lipid extraction (polar, nonpolar and neutral fractions) depending of the food matrix (Bligh \& Dyer, 1959; Conte-Junior et al., 2007; Ryckebosch et al., 2012). In addition, Bligh and Dyer method not requires reflux distillation apparatus decreasing the analysis time and solvent amount used during analytical procedure.

Regarding lipid oxidation, MDA measurement proposed by Tarladgis et al. (1960) present some analytical limitations such as distillation step (long time analysis and excessive use of water) and heating process which can catalyze lipid oxidation. On the other hand, MDA methodology described by Yin et al. (1993) is a simple and fast method based on cold extraction without distillation step.

The aforementioned methods are widely used for determination of the total lipid content and lipid oxidation in several food matrices, including freshwater fish species. Nonetheless, to the best of our knowledge, a comparative study between Soxhlet and Bligh and Dyer methods as well as the analytical techniques proposed by Tarladgis et al. (1960) and Yin et al. (1993) was not conducted in freshwater fishes with different fat levels. In this context, the aim of the present study was to investigate the efficiency of analytical techniques for total lipid determination and oxidative rancidity evaluation in freshwater fishes with different fat levels.

\section{Materials and Methods}

\subsection{Samples}

Two species of freshwater fishes with different lipid levels were used, Cichla ocellaris which can be considered a lean fish $(<2 \%)$, and Piaractus brachypomus which presents high total lipid amount (>8\%) (Haard, 1992). Fish samples were collected in a fish farming located in Goiás, Brazil. The mean and the standard deviation of the length $(\mathrm{cm})$ and weight $(\mathrm{g})$ of the samples were calculated. The length and the weight of Cichla ocellaris were $36.57 \pm 0.51 \mathrm{~cm}$ and $861.1 \pm 32.59 \mathrm{~g}$, respectively. For Piaractus brachypomus the length and weigh were $39.77 \pm 1.27 \mathrm{~cm}$ and $1205.8 \pm 104.59 \mathrm{~g}$, respectively. Samples were transported in insulated container with ice to the laboratory where the analyzes were made. The time from sample obtaining until arrival at the laboratory did not exceed 8 hours.

\subsection{Total lipid content}

Total lipid content was determined by Soxhlet extraction method using petroleum ether solvent (Soxhlet, 1879) and by Bligh and Dyer method using methanol-chloroform $(2: 1, \mathrm{v} / \mathrm{v})$ (Bligh \& Dyer, 1959).

\subsection{Lipid oxidation}

Oxidative rancidity was measured according to method described by Tarladgis et al. (1960) and Yin et al. (1993). In the first method, sample $(10 \mathrm{~g})$ was homogenized with $97.5 \mathrm{~mL}$ of distilled water, $2.5 \mathrm{~mL}$ of hydrochloric acid $(4 \mathrm{~N})$ was added, and samples were distilled to obtain $50 \mathrm{~mL}$. An aliquot of $5 \mathrm{~mL}$ was transferred to a tube and $5 \mathrm{~mL}$ of TBA solution 
$(20 \mathrm{mM})$ was added. The tube was heated at $60^{\circ} \mathrm{C}$ for 35 minutes and cooled at $4^{\circ} \mathrm{C}$ for 10 minutes in running water. After, reading was carried out in UV-1800 spectrophotometer (Shimadzu, Kyoto, Japan) at $538 \mathrm{~nm}$ (Tarladgis et al., 1960). In the second method, sample $(5 \mathrm{~g})$ was homogenized with $22.5 \mathrm{~mL}$ of trichloroacetic acid (11\%), filtered with Whatman paper $\mathrm{n}^{\circ} 1$. An aliquot of $5 \mathrm{~mL}$ was transferred to a tube and $5 \mathrm{~mL}$ of TBA solution $(20 \mathrm{mM})$ was added. The tube was incubated in dark conditions for 20 hours. The reading was performed in UV-1800 spectrophotometer (Shimadzu, Kyoto, Japan) at $532 \mathrm{~nm}$ (Yin et al., 1993).

\subsection{Statistical analysis}

One-way ANOVA with post test $\mathrm{T}$ Student at 5\% significance level was used to identify separately differences between the methods applied (Soxhlet versus Bligh and Dyer for total lipid determination, and hot versus cold extraction for MDA measurement) for both species studied. For statistical analysis was used the program XLSTAT version 2012.6.08 (Addinsoft, Paris, France).

\section{Results and Discussion}

\subsection{Total lipid content}

Total lipid content in two freshwater fish species evaluated by Soxhlet (1879) and Bligh and Dyer (1959) methods are exhibited in Table 1. The Bligh and Dyer (1959) method extracted greater lipid content $(P<0.05)$ than Soxhlet $(1879)$ method in both Cichla ocellaris and Piaractus brachypomus species. Previous studies also reported this difference between Soxhlet (1879) and Bligh and Dyer (1959) methods in fish species such as Clupea harengus, Salmo salar, Gadus morhua, Esox Lucius (Ewald et al., 1998), Trachurus trachurus, Scomber japonicas, and Sardina pilchardus (Ramalhosa et al., 2012), whereas ricotta cream (Gusso et al., 2012) and meat (Tanamati et al., 2005).

This fact can be explained by solvent mixture used in Bligh and Dyer method resulting in a great lipid extraction with broad range of polarity (Bligh \& Dyer, 1959). In this method, total lipid content is extracted by a solvent mixture (chloroform-methanol-water) which is able of recovering non-polar, polar and neutral lipids (Brum et al., 2009). Furthermore, the vigorous homogenization process performed in Bligh and Dyer (1959) method making the lipid extraction more efficient (Brum et al., 2009). Another advantage of this method includes less time required (Martins et al., 2015). On the other hand, the Soxhlet method (1879) is based on use of a single solvent resulting only in non-polar lipid extraction ( $\mathrm{Lu}$ et al., 2015). Maia et al. (1995) reported that fish genus Piaractus contain 94\% of neutral lipids. Therefore, the use of a single solvent is not recommended for the lipid extraction of animal tissue demonstrating the major efficiency of the Bligh and Dyer (1959) method in this type of food matrix (Brum et al., 2009). Moreover, the methodology proposed by Sohxlet (1879) presents a long heating step leading to interference in the results due to peroxides formation and acidity increased (Brum et al., 2009). Regarding lipid amount, Bligh and Dyer (1959) method exhibited a great lipid extraction even in low-fat fish species $(3.8 \%)$ indicating that the lipid content of fish matrix does not influence on lipid extraction capacity of this method (Maia et 
al., 1999). Moreover, Ramalhosa et al. (2012) to quantify the content of lipids in the species Scomber japonicas showed that the Bligh and Dyer (1959) method also demonstrated superior results in fish with high fat content. Our findings indicate that Bligh and Dyer (1959) method is more efficient for lipid extraction of freshwater fish species up to approximately $12 \%$ of fat.

\subsection{Lipid oxidation}

Malondialdehyde (MDA) values of the two freshwater fish species using methods proposed by Tarladgis et al. (1960) and Yin et al. (1993) are presented in Table 2. The heat method (Tarladgis et al., 1960) exhibited greater MDA values $(P<0.05)$ than cold method (Yin et al., 1993) in both fish species. High temperatures and strong acidic conditions, which are required in Tarladgis et al. (1960) method, can result in possible artefactual peroxidation leading to overestimation of MDA amount (Mendes et al., 2009).

In agreement with our results, Tokur et al. (2006) observed greater MDA values in heat method than cold method in Sardina pilchardus, Mugil cephalus, Sarda sadra and Pomatomus saltator. In addition, Ulu (2004) evaluating lipid oxidation methods in chicken meat and meat products, respectively, also observed that heat method exhibit greater MDA values than cold method. Moreover, this author reported that the degree of differentiation between heat and cold methods is proportional to amount of unsaturated fat in the food matrices. The lipid oxidation is directly related to unsaturated fatty acids composition due to chemical instability of the double bonds (Martínez-Yusta et al., 2014) which can explain the great MDA values in the low fat fish species (Cichla ocellaris). The fatty acid composition is variable between both freshwater fishes evaluated. According to Inhamuns et al. (2009), Cichla ocellaris presents $35.8 \%$ of polyunsaturated fatty acids (PUFA), including high amounts of eicosapentaenoic (EPA) and docosahexaenoic (DHA) acids whereas Piaractus brachypomus contain $32.5 \%$ of PUFA (Murthy et al., 2015).

Therefore, our study suggests that cold method is able of generate MDA results more reliable than heat method. Moreover, the method described by Tarladgis et al. (1960) demonstrated a great coefficient of variation than Yin et al. (1993) in both fish species studied, possibly due to high number of analytical steps in this method. According to Fourier et al. (2015) the high variability of results is related to the analytical phase. In addition, the high temperature employed in heat method can be considered an interfering because the heating process may accelerate the occurrence of lipid oxidation and the TBA reaction with other components of the food matrix (Mendes et al., 2009). Similarly to our results, previous studies (Pikul et al., 1989; Wang et al., 1997) demonstrated that heat method presented greater coefficient of variation in the MDA data $(15 \% ; 2.9 \%)$ than cold method $(9.5 \% ; 1.6 \%)$ in meat products and fish, respectively.

Lipid oxidation is a chain reaction with the production of free radicals wherein unsaturated fatty acids present in the food matrix react with oxygen to form peroxides, hydroperoxides and secondary compounds such as aldehydes, alkanes and conjugated dienes which are from the hydroperoxides decomposition (Pacheco et al., 2010; Salcedo-Sandoval et al., 2015). Among the compounds from decomposition of polyunsaturated fatty acids, MDA is 
considered the main secondary compound, which presents a great importance due to toxic effect on human health (Karlsdottir et al., 2014; Zaki et al., 2014). MDA increased leads to a lower paraoxonase (PON1) level contributing to the greater risk of dyslipidemia, insulin resistance, and high blood pressure (Zaki et al., 2014). Moreover, high MDA levels generate health damages such as inefficiency on nutrient metabolism, detrimental effects on cell functionality and structure, and atherosclerosis (Albert et al., 2013; Palmeira et al., 2014b).

Another consequence of the secondary compounds from lipid oxidation is the negative effects on the sensory aspects of the food such as undesirable odor and flavor which limits the food shelf-life during storage. In addition, the secondary compounds negatively impact on nutritive value (Karlsdottir et al., 2014; Ladeira et al., 2014; Vieira et al., 2015).

In this context, the lipid oxidation measurement is highly relevant for monitoring food quality and human health. Although the importance of this parameter, there are no limits established for MDA values by legislation. Therefore, it is important to define MDA limits in fish as well as establish a standard analytical method for the evaluation of this parameter in order to avoid doubtful values due to different methodologies employed.

\section{Conclusion}

Bligh and Dyer (1959) technique must be the method choice for lipid extraction in freshwater fish species independently of fat levels. Furthermore, the cold method for MDA quantification proposed by Yin et al. (1993) may be a viable alternative for official monitoring of lipid oxidation in fish, producing accurate and reliable data due to non-interference of the heating step. Moreover, Bligh and Dyer (1959) and Yin et al. (1993) methodologies also require less amount of solvents and analysis time for determination of total lipid content and oxidative rancidity, respectively.

\section{Acknowledgments}

The authors are thankful for the financial support from the Fundação Carlos Chagas Filho de Amparo à Pesquisa do Estado do Rio de Janeiro (FAPERJ), process numbers E-26/111.673/2013; $\quad$ E-26/010.001954/2014; E-26/201.185/2014; $\quad$ E-26/111.130/2014; E-26/110.094/2014; E-26/010.001961/2014; E-26/010.001911/2014 and E-26/101.403/2014; from the Conselho Nacional de Desenvolvimento Científico e Tecnológico (CNPq) process numbers $\quad 311361 / 2013-7, \quad 401922 / 2013-8, \quad 313917 / 2013-2, \quad 442102 / 2014-3 \quad$ and 441987/2014-1; and also from the Coordenação de Aperfeiçoamento de Pessoal de Nível Superior (CAPES), process number CAPES/FAPERJ E-45 - PAPDRJ/2013 (E-26/101.403/2014).

\section{References}

Ahmed, G. E., Souleman, M. A., Eid, M. M., \& Shabaan, H. A. (2014). Phenoilc composition, antiradical activity and effect on hexanal of olive mill wastewater. World Applied Sciences Journal, 32, 2178-2185. http://dx.doi.org/ 10.5829/idosi.wasj.2014.32.11.9125 
Albert, B. B., Cameron-Smith D., Hofman P. L., \& Cutfield W. S. (2013). Oxidation of marine omega-3 supplements and human health. BioMed Research International, 2013, 1-8. http://dx.doi.org/10.1155/2013/464921

AOAC. (2012). Official methods of analysis. Arlington: AOAC.

Bertolin, T. E., Guarienti, C., Farias, D., Souza, F. T., Gutkoski, L. C., \& Colla, L. M. (2011). Antioxidant effect of phycocianin on dried-salted fish. Ciência e Agrotecnologia, 35, 751-757. http://dx.doi.org/10.1590/S1413-70542011000400014

Bligh, E. G., \& Dyer, W. J. (1959). A rapid method of total lipid extraction and purification.Canadian Journal of Biochemistry Physiology, 37, 911-991. http://dx.doi.org/10.1139/o59-099

Brum, A. A. S., Arruda, L. F., \& Arce, M. A. B. R. (2009). Método de extração e qualidade da fração lipídica de matérias-primas de origem vegetal e animal. Química Nova, 32, 849-854. http://dx.doi.org/10.1590/S0100-40422009000400005

Canto, A. C. V. C. S., Costa-Lima, B. R. C., Suman, S. P., Monteiro, M. L. G., Marsico, E. T., Conte-Junior, C. A., ... Silva, T. J. P. (2015). Fatty acid profile and bacteriological quality of caiman meat subjected to high hydrostatic pressure. LWT - Food Sciences and Technology, 63, 872-877. http://dx.doi.org/10.1016/j.lwt.2015.05.003

Chaijan, M. (2008). Review: Lipid and myoglobin oxidations in muscle foods. Songklanakarin Journal of Sciences and Technology, 30, 47-53. http://rdo.psu.ac.th/sjstweb/journal/30-1/0125-3395-30-1-47-53.pdf

Chowdhury, R., Stevens, S., Gorman, D., Pan, A., Warnakula, S., Chowdhury, S., ... Franco, O. H. (2012). Association between fish consumption, long chain omega 3 fatty acids, and risk of cerebrovascular disease: systematic review and meta-analysis. BMJ, 345, 1-9. http://dx.doi.org/10.1136/bmj.e6698

Collewet, G., Bugeon, J., Idier, J., Quellec, S., Quittet, B., Cambert, M., \& Haffray, P. (2013. Rapid quantification of muscle fat content and subcutaneous adipose tissue in fish using MRI. Food Chemistry, 138, 2008-2015. http://dx.doi.org/10.1016/j.foodchem.2012.09.131

Contarini, G., \& Povolo, M. (2013). Phospholipids in Milk Fat: Composition, Biological and Technological Significance, and Analytical Strategies. International Journal of Molecular Sciences, 14, 2808-2831. http://dx.doi.org/10.3390/ijms14022808

Conte Junior, C. A., Soncin, S., Hierro, E., \& Fernández, M. (2007). Estudio de la producción de ácido linoleico conjugado por cepas de Lactobacillus sp. y Enterococcus sp. de distintos orígenes. Revista Complutense de Ciencias Veterinarias, 2, 482-489. http://dx.doi.org/10.1002/fsn3.200

Dey, S., Misra, K. K., \& Homechoudhuri, S. (2015). Lipid classes and fatty acids of a freshwater Indian minor carp, Amblypharyngodon mola. International Journal of Research in Fisheries and Aquaculture, 5, 5-18. http://urpjournals.com/tocjnls/35_15v5i1_2.pdf 
Duthie, G., Campbell, F., Bestwick, C., Stephen, S., \& Russell, W. (2013). Antioxidant effectiveness of vegetable powders on the lipid and protein oxidative stability of cooked turkey meat patties: Implications for health. Nutrients, 5, 1241-1252. http://dx.doi.org/10.3390/nu5041241

Ewald, G., Bremle, G., \& Karlsson, A. (1998). Differences between Bligh and Dyer and Soxhlet extractions of PCBs and lipids from fat and lean fish muscle: Implications for data evaluation. Mmine Pollution Bullelin, 36, 222-230. http://dx.doi.org/10.1016/S0025-326X(97)00176-8

Fourier, A., Portelius, E., Zetterberg, H., Blennow, K., Quadrio, I., \& Perret-Liaudet, A. (2015). Pre-analytical and analytical factors influencing Alzheimer's disease cerebrospinal fluid biomarker variability. Clinica Chimica Acta, 449, 9-15. http://dx.doi.org/10.1016/j.cca.2015.05.024

Gusso, A. P., Mattanna, P., Pellegrini, L. G., Cassanego, D. B., Richards, N. S. P. S., \& Ribeiro, A. S. (2012). Comparação de diferentes métodos analíticos para quantificação de lipídios em creme de ricota. Revista Instituto Laticinios Cândido Tostes, 67, 51-55. http://dx.doi.org/10.5935/2238-6416.20120078

Haard, N. F. (1992). Control of chemical composition and food quality attributes of cultured fish. Food Research International, 289-307. http://dx.doi.org/10.1016/0963-9969(92)90126-P

Inhamuns, A. J., Franco, M. R. B., \& Batista, W. S. (2009). Seasonal variations in total fatty acid composition of muscles and eye sockets of tucunaré (Cichla sp.) from the Brazilian $\begin{array}{lllll}\text { Amazon } \text { area. } & \text { Food } 272-275 .\end{array}$ http://dx.doi.org/10.1016/j.foodchem.2009.03.113

Ikami, T., Ishida, H., \& Kiso, M. (2000). Synthesis and boilogical activity of glycolipids, with a focus on gangliosides and sulfatide analogs. Methods Enzymology, 311, 547-568. http://dx.doi.org/10.1016/S0076-6879(00)11105-X

Iverson, S. J., Lang, S. L. C., \& Cooper, M. H. (2001). Comparison of the Bligh and Dyer and Folch methods for total lipid determination in a broad range of marine tissue. Lipids, 36, 1283-1287. http://dx.doi.org/10.1007/s11745-001-0843-0

Karlsdottir, M. G., Sveinsdottir, K., Kristinsson, H. G., Villot, D., Craft, B. D., \& Arason, S. (2014). Effect of thermal treatment and frozen storage on lipid decomposition of light and dark muscles of saithe (Pollachius virens). Food Chemistry, 164, 476-484. http://dx.doi.org/10.1016/j.foodchem.2014.05.068

Kus, M. M. M., Aued-Pimentel, S., \& Mancini-Filho, J. (2009). Comparison of analythical methods in determination of lipids and polyunsatured fatty acids by gas chromatography in infant formula. Revista Instituto Adolfo Lutz, 68, 12-20. http://revistas.bvs-vet.org.br/rialutz/article/view/6971/7189 
Ladeira, M. M., Santarosa, L. C., Chizzotti, M. L., Ramos, E. M., Machado Neto, O. R., Oliveira, D. M., ... Ribeiro, J. S. (2014). Fatty acid profile, color and lipid oxidation of meat from young bulls fed ground soybean or rumen protected fat with or without monensin. Meat Science, 96, 597-605. http://dx.doi.org/10.1016/j.meatsci.2013.04.062

Maia, E. L., Rodriguez-Amaya, D. B., \& Hotta, L. K. (1995). Fatty acids composition of the total, neutral and phospholipids of pondraised Brazilian Piaractus mesopotamicus. International Food Science and Technology, 30, 591-597. http://dx.doi.org/10.1111/j.1365-2621.1995.tb01407.x

Maia, E. L., Oliveira, C. C. S., Santiago, A. P., Cunha, F. E. A., Holanda, F. C. A, \& Sousa, J.A. (1999). Composição química e classes de lipídios em peixe de água doce Curimatã comum, Prochilodus cearenses. Ciência e Tecnologia de Alimentos, 19, 433-437. http://dx.doi.org/10.1590/S0101-20611999000300025

Mársico, E. T., Silva, C., Barreira, V. B., Mantilla, S. P. S., \& Moraes, I. A. (2009). Parâmetros físico-químicos de peixe salgado e seca (bacalhau) comercializado em mercados $\begin{array}{lllll}\text { varejistas. Revista Instituto Adolfo Lutz, 68, } & \text { 406-410. }\end{array}$ http://revistas.bvs-vet.org.br/rialutz/article/view/6807/6943

Martínez-Yusta, A., Goicoechea, E., \& Guillén, M. D. (2014). A Review of Thermo-Oxidative Degradation of Food Lipids Studied by ${ }^{1} \mathrm{H}$ NMR Spectroscopy: Influence of Degradative Conditions and Food Lipid Nature. Comprehensive Reviews Food Science and Food Safety, 13, 838-859. http://dx.doi.org/ 10.1111/1541-4337.12090

Martins, F. S., \& Conceição, E. C. (2015). Evaluation of extraction method on the chemical composition in Apeiba tibourbou Aubl's extracts. Pharmacognosy magazine, 11, 368-373. http://dx.doi.org/ 10.4103/0973-1296.153091

Mendes, R., Cardoso, C., \& Pestana, C. (2009). Measurement of malondialdehyde in fish: A comparison study between HPLC methods and the traditional spectrophotometric test. Food Chemistry, 112, 1038-1045. http://dx.doi.org/ 10.1016/j.foodchem.2008.06.052

Monteiro, M. L. G., Mársico, E. T., Teixeira, C. E., Mano, S. B., Conte-Júnior, C. A., \& Vital, H. C. (2012). Validade comercial de filés de Tilápia do Nilo (Oreochromis niloticus) resfriados embalados em atmosfera modificada e irradiados. Ciência Rural, 42, 737-743. http://dx.doi.org/10.1590/S0103-84782012000400027

Monteiro, M. L. G., Mársico, E. T., Lázaro, C. A., Canto, A. C. V. C. S., Costa-Lima, B. R. C., Cruz, A. G., \& Conte Júnior, C. A. (2015). Effect of transglutaminase on quality characteristics of a value-added product tilapia wastes. Journal of Food Sciences and Technology, 52, 2598-2609. http://dx.doi.org/10.1007/s13197-014-1327-5

Murthy, L. N., Madhusudana, B. R., Asha, K. K., \& Prasad, M. M. (2015). Nutritional composition, product development, shelf-life evaluation and quality assessment of pacu Piaractus brachypomus (Cuvier, 1818). Indian Journal Fisheries, 62, 101-109. 
Pacheco, J., Núñez, A. L., \& Espinoza, A. (2010). Estabilidad fisicoquímica durante el almacenamiento refrigeradode filetes de bagre dorado (Brachyplatystomarousseauxii) ahumados y empacados con y sin vacío. Revista Científica UDO Agrícola, 10, 123-132.

Palmeira, K. R., Rodrigues, B. L., Gaze, L. V., Freitas, M. Q., Teixeira, C. E., Mársico, E. T., Cruz, A. G., \& Conte-Junior, C. A.(2014a). Use of transglutaminase, soybean waste and salt replacement in the elaboration of trout (Oncorhynchus mykiss) meatball. International of Food Research Journal, 21, 1597-1602.

Palmeira, K. R., Mársico, E. T., Doro, L., Lemos, M., Teixeira, C. E., Paschoalin, V. M. F., Monteiro, M. L. G., \& Conte-Júnior, C. A. (2014b). Quality of semi-prepared products from rainbow trout waste (Onchorynchus mykiss) by using different technological strategics. Food Nutritional Science, 5, 571-580. http://dx.doi.org/10.4236/fns.2014.56067

Pikul, J., Leszczynski, D. E., \& Kummerow, F. A. (1989). Evaluation of three modified TBA methods for measuring lipid oxidation in chicken meat. Journal of Agriculture and Food Chemistry, 37, 1309-1313. http://dx.doi.org/ 10.1021/jf00089a022

Ramalhosa, M. J., Paíga, P., Morais, S., Alves, M. R., Matos, C. D., \& Oliveira, M. B. P. P. (2012). Lipid content of frozen fish: Comparison of different extraction methods and variability during freezing storage. Food Chemistry, 131, 328-336. http://dx.doi.org/10.1016/j.foodchem.2011.07.123

Ryckebosch, E., Muylaert, K., \& Foubert, I. (2012). Optimization of an analytical procedure for extraction of lipids from microalgae. Journal of the American Oil Chemists Society, 89, 189-198. http://dx.doi.org/ 10.1007/s11746-011-1903-z

Soxhlet, F. (1879). The weight analytic determination of milk fat. Polytechnisches Journal, 232, 461-465. http://dingler,culture.huberlin.de/article/pj232/ar232136

Tarladgis, B. G., Watts, B. M., Younathan, M. T., \& Dugan, J. L. (1960). A distillation method for the quantitative determination of malonaldehyde in rancid foods. Journal of the American Oil Chemists Society, 37, 44-48. http://dx.doi.org/10.1007/BF02630824

Tanamati, A., Oliveira, C. C., Visentainer, J. V., Matsushita, M., \& Souza, N. E. (2005). Comparative study of total lipids in beef using chlorinated solvent and low-toxicity solvent methods. Journal of the American Oil Chemists Society, 82, 393-397. http://dx.doi.org/ $10.1007 / \mathrm{s} 11746-005-1083-4$

Tocher, D. R., \& Glencross, B. D. (2015). Lipids and Fatty Acids. In C. S. Lee, C. Lim, D. M. Gatlin III, \& C. D. Webster (Eds.), Dietary Nutrients, additives, and fish health (pp. 47-94). New Jersey: Wiley-Blackwell.

Tonial, I. B., Matsushita, M., De Souza, N. E., Perini, J. A. L., De Morais, D. R., Bani, F.A., \& Visentainer, J. V. (2009). Avaliação de diferentes métodos de extração lipídica sobre a composição de ácidos graxos poliinsaturados em leite de vaca. Archivos Latinoamericanos de Nutricion, 59, 78-81. 


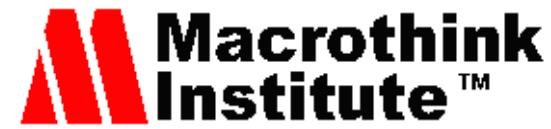

Journal of Food Studies ISSN 2166-1073

Tokur, B., Korkmaz, K., \& Ayas, D. (2006). Comparison of two thiobarbituric acid (TBA) method for monitoring lipid oxidation in fish. Journal of Fisheries \& Aquatic Sciences, 23, 331-334.

Ulu, H. (2004). Evaluation of three 2-thiobarbituric acid methods for the measurement of lipid oxidation in various meats and meat products. Meat Science, 67, 683-687. http://dx.doi.org/10.1016/j.meatsci.2003.12.014

Vieira, S. A., McClements, D. J., \& Decker E. A. (2015). Challenges of utilizing healthy fats in foods. Advances in Nutrition, 6, 309-317. http://dx.doi.org/10.3945/an.114.006965

Yin, M. C., Faustman, C., Riesen, J. W., \& Williams, S. N. (1993). $\alpha$-Tocopherol and ascorbate delay oxymyoglobin and phospholipid oxidation in vitro. Journal of Food Science, 58, 1273-1276. http://dx.org.doi/10.1111/j.1365-2621.1993.tb06164.x

Youn, S. J., Taylor, W. W., Lynch, A. J., Cowx, I. G., Beard, J. T. D., Bartley, D., \& Wu, F. (2014). Inland capture fishery contributions to global food security and threats to their future. Global Food Security, 3, 142-148. http://dx.doi.org/ 10.1016/j.gfs.2014.09.005

Wang, C., Zhu, L., \& Brewer, M. S. (1997). Comparison of 2-thiobarbituric acid reactive substances determination methods in various types of frozen, fresh meat. Journal of Food Lipids, 4, 87-96. http://dx.doi.org/ 10.1111/j.1745-4522.1997.tb00083.x

Wijaya, C. H., Wijaya, W., \& Mehta, B. M. (2015). General properties of major food components. In P. C. K. Cheung, \& B. M. Mehta (Eds.), Handbook of Food Chemistry (pp. 1-32). Berlin: Springer.

Zaki, M. E., El-Eassyouni, H., Kamal, S., El-Gammal, M., \& Youness, E. (2014). Association of serum paraoxonase enzyme activity and oxidative stress markers with dyslipidemia in obese adolescents. Indian Journal Endocrinology of Metabolism, 18, 340-344. http://dx.doi.org/10.4103/2230-8210.131173

Table 1. Total lipid content (\%) in two freshwater fish species by two different extraction methods

\begin{tabular}{lll}
\hline Species & Soxhlet & Bligh and Dyer \\
\hline Cichla ocellaris $^{1}$ & $0.88^{\mathrm{a}} \pm 0.00^{*}(0.11)^{\#}$ & $1.62^{\mathrm{b}} \pm 0.00^{*}(0.18)^{\#}$ \\
Piaractusbrachypomus $^{2}$ & $9.20^{\mathrm{a}} \pm 0.00 *(0.01)^{\#}$ & $11.27^{\mathrm{b}} \pm 0.01 *(0.14)^{\#}$ \\
\hline
\end{tabular}

${ }^{1}$ Lean fish; ${ }^{2}$ Fish with high fat content (Haard, 1992).

${ }^{\mathrm{a}, \mathrm{b}}$ Different letters in the same row indicate significant differences $(P<0.05)$; * Mean \pm standard deviation; ${ }^{\#}$ (Values in parentheses represent coefficient of variation \%). 


\section{Macrothink}

Journal of Food Studies

ISSN 2166-1073

2015, Vol. 4, No. 1

Table 2. Malondialdehyde (MDA) values (absorbance) in two freshwater fish species by two different extraction methods

\begin{tabular}{lll}
\hline Species & Tarladgis et al. $^{¥}$ & Yin et al. $^{¥}$ \\
\hline Cichla ocellaris $^{1}$ & $0.186^{\mathrm{a}} \pm 0.079 *(42.4)^{\#}$ & $0.101^{\mathrm{b}} \pm 0.017^{*}(16.8)^{\#}$ \\
Piaractus brachypomus $^{2}$ & $0.120^{\mathrm{a}} \pm 0.078^{*}(65.0)^{\#}$ & $0.039^{\mathrm{b}} \pm 0.004^{*}(10.2)^{\#}$ \\
\hline
\end{tabular}

${ }^{1}$ Lean fish; ${ }^{2}$ Fish with high fat content (Haard, 1992).

${ }^{\mathrm{a}, \mathrm{b}}$ Different letters in the same row indicate significant differences $(P<0.05)$; * Values are means \pm standard deviation; $\quad$ (Values in parentheses represent coefficient of variation \%).

${ }^{¥}$ Heat and cold methods proposed by Tarladgis et al. (1960) and Yin et al. (1993), respectively. Results are absorbance in $538 \mathrm{~nm}$ and $532 \mathrm{~nm}$, respectively. 